\title{
SIMULASI DIAMETER GEL BASAH \\ PADA FABRIKASI KERNEL YTTRIA-STABILIZED ZIRCONIA MENGGUNAKAN ALAT GEL-CASTING
}

\author{
Erilia Yusnitha ${ }^{1}$, Sarjono ${ }^{1}$, Sri Rinanti Susilowati ${ }^{1}$, \\ Winter Dewayatna ${ }^{1}$, Wahyudi Budi Sediawan ${ }^{2}$ \\ ${ }^{1}$ Pusat Teknologi Bahan Bakar Nuklir - BATAN \\ Kawasan Puspiptek Serpong Gd.20 Tangerang Selatan, Banten 15314 \\ ${ }^{2}$ Departemen Teknik Kimia, Fakultas Teknik - Universitas Gadjah Mada \\ Jalan Grafika No.2 Yogyakarta 55281 \\ e-mail: erilia@batan.go.id
}

(Naskah diterima: 19-11-2018, Naskah direvisi: 05-12-2018, Naskah disetujui: 12-12-2018)

\begin{abstract}
ABSTRAK
SIMULASI DIAMETER GEL BASAH PADA FABRIKASI KERNEL YTTRIA-STABILIZED ZIRCONIA MENGGUNAKAN ALAT GEL-CASTING. Pada proses pembuatan kernel yttriastabilized zirconia (YSZ), broth diteteskan melalui alat gel-casting untuk membentuk gel basah YSZ. Broth adalah umpan alat gel-casting yang berupa larutan terdiri dari zirconium (IV) nitrate, yttrium (III) nitrate hexahydrate, urea, tetrahydrofurfuryl alcohol (THFA), dan poly vinyl alcohol (PVA). Parameter proses alat gel-casting seperti frekuensi vibrasi dan kecepatan aliran broth diatur untuk memperoleh bentuk dan ukuran diameter gel basah yang diinginkan. Alat gel-casting yang berada di PTBBN BATAN memiliki satu buah nozzle dengan diameter $1 \mathrm{~mm}$. Kegiatan simulasi ini perlu dilakukan untuk mengurangi jumlah eksperimen di laboratorium sehingga mengurangi volume limbah yang diakibatkan trial and error dalam eksperimen. Selain itu, simulasi ini bertujuan untuk memprediksi diameter gel basah yang dihasilkan. Oleh karena itu, simulasi diameter gel basah perlu dilakukan dan diverifikasi dengan hasil eksperimen. Berdasarkan hipotesa, simulasi diameter gel basah dapat dilakukan dengan memperhitungkan parameter alat gel-casting seperti kecepatan aliran broth dan frekuensi vibrasi. Selain itu karakteristik dari broth seperti densitas juga mempengaruhi diameter gel basah. Diameter gel basah yang dihasilkan alat gel-casting diukur menggunakan alat mikroskop digital. Diameter gel basah dari eksperimen didekati menggunakan persamaan yang dimodifikasi dengan memperhitungkan frekuensi vibrasi, kecepatan aliran broth, konsentrasi metal dalam broth dan densitas broth. Hasil simulasi menunjukkan penyimpangan yang lebih kecil dari simulasi menggunakan persamaan sederhana yang hanya memperhitungkan frekuensi vibrasi dan kecepatan aliran broth.
\end{abstract}

Kata kunci: simulasi, diameter, gel basah, broth, alat gel-casting 


\section{ABSTRACT}

SIMULATION OF MICROSPHERE OF GELLED KERNELS DIAMETER IN THE FABRICATION OF YTTRIA-STABILIZED ZIRCONIA WITH GEL-CASTING EQUIPMENT. In kernel fabrication, microsphere of gelled kernels (yttria-stabilized zirconia) were made by droplet formation of the broth through the gel-casting equipment. Broth is feed of gel-casting equipment that were made of mixed ofzirconium (IV) nitrate, yttrium (III) nitrate hexahydrate, urea, tetrahydrofurfuryl alcohol (THFA), and poly vinyl alcohol (PVA). The process parameter of the gel-casting equipment such as vibration frequency and broth flowrate need to be set up to control shape and diameter of the targeted microsphere of gelled kernels. The gel-casting equipment at PTBBN - BATAN is equipped with single nozzle with $1 \mathrm{~mm}$ diameter. The simulation work is important to be carried out to reduce the number of experiments in the laboratory hence it reduces the waste from trial and error in the experiment. Moreover, the objective of this simulation work is to predict the diameter of microsphere of gelled kernels. Therefore, the simulation of microsphere of gelled kernel diameter is necessary to be build and verified with the experiment data. According to hypothesis, the simulation of microsphere of gelled kernel diameter can be conducted by considering gel-casting equipment parameter such as the broth flowrate and vibration frequency. In addition, the broth characteristic as broth density affects the diameter of microsphere of gelled kernels diameter. The diameter of microsphere of gelled kernels produced from gel-casting equipment were determined with digital microscope. The result from simulation calculation shows that diameter of microsphere of gelled kernels produced from laboratory experiment can be approached by modified equation involving vibration frequency, broth flowrate, metal concentration in the broth and broth density. It appears that the deviation of simulation calculation is smaller than simple equation, where only vibration frequency and broth flowrate are included in the calculation.

Keywords: simulation, diameter, microsphere of gelled kernels, broth, gel-casting equipment. 


\section{PENDAHULUAN}

Reaktor Daya Eksperimental (RDE) yang sedang dikembangkan oleh BATAN merupakan reaktor bertipe HighTemperature Gas-Cooled Reactor (HTGR). Bahan bakar reaktor gas temperatur tinggi dapat diproduksi dalam bentuk prismatik atau pebble [1]. Bahan bakar pebble telah digunakan untuk reaktor temperature tinggi Pebble bed Module (HTR-PM), 10 MW HTR (HTR-10) di Cina [2] dan PBMR di Afrika Selatan, sedangkan bahan bakar bentuk prismatik digunakan untuk reaktor GT-MHR di Amerika dan HTTR di Jepang [1]. Bahan bakar bentuk prismatik dan pebble terdiri dari sejumlah besar partikel terlapisi. Bagian tengah dari partikel terlapisi adalah kernel yang dibuat dari uranium oksida $\left(\mathrm{UO}_{2}\right)[3,4]$, uranium karbida $\left(\mathrm{UC}+\mathrm{UC}_{2}\right)$ [4], uranium oksikarbida (UCO) [4,5] dan uranium nitrida [6]. Kernel ini kemudian dilapisi dengan beberapa lapisan yang terdiri dari lapisan buffer, lapisan pyrolytic carbon (IPyC and $\mathrm{OPyC}$ ) and silikon karbida (SiC) [3,7] untuk membentuk tri-structural isotropic (TRISO) [7] menggunakan alat fluidized bed chemical vapor deposition $[8,9]$.

Dalam produksi partikel terlapisi yang memenuhi persyaratan untuk bahan bakar reaktor gas temperatur tinggi, diperlukan produksi kernel yang memenuhi kendali kualitas dan jaminan mutu dari persyaratan kernel. Salah satu persyaratan kendali kualitas dari kernel adalah memiliki sferisitas yang baik dan penyimpangan diameter kernel yang kecil [10]. Upaya untuk keperluan eksperimen, kernel bahan bakar nuklir dapat digantikan dengan bahan non radioaktif seperti zirkonia [1,11], yttria-stabilized zirconia [12] dan cerium dioksida [13]. Teknik broth-gel untuk fabrikasi kernel ada 3 jenis yaitu gelasi ektraksi air [4],gelasi internal [14] and gelasi eksternal [2].

Proses pembuatan kernel yang dilakukan di Pusat Teknologi Bahan Bakar Nuklir (PTBBN)-BATAN menggunakan cara gelasi eksternal. Salah satu persyaratan kendali kualitas untuk kernel adalah kontrol diameter yang akurat. Diameter kernel berhubungan erat dengan diameter gel basah yang dihasilkan dari alat gel-casting. Kegiatan simulasi diameter gel basah ini dilakukan untuk mengurangi jumlah eksperimen di laboratorium, sehingga mengurangi volume limbah yang diakibatkan trial and error selama proses eksperimen. Hingga saat ini, belum diketahui ada karya tulis ilmiah maupun jurnal yang melakukan simulasi diameter gel basah menggunakan yttria-stabilized-zirconia (YSZ) untuk menentukan parameter pengoperasian alat gelcasting yang dimiliki PTBBN-BATAN. Perhitungan simulasi yang disediakan dalam makalah ini dapat memberikan pemahaman awal tentang cara memprediksi diameter gel basah YSZ pada berbagai parameter proses alat gel-casting, antara lain frekuensi vibrasi dan kecepatan aliran broth.

\section{TEORI}

Proses pembuatan kernel dimulai dengan preparasi broth. Broth adalah umpan alat gel-casting yang berupa larutan terdiri dari zirconium (IV) nitrate, yttrium (III) nitrate hexahydrate, urea, tetrahydrofurfuryl alcohol (THFA), dan poly vinyl alcohol (PVA). Pembuatan droplet dilakukan dengan menggunakan alat gel-casting. Cara kerja alat gel-casting ini dengan meneteskan broth dengan menggunakan vibrasi pada frekuensi tertentu sehingga berbentuk droplet ke dalam kolom yang berisi larutan ammonium hidroksida $\left(\mathrm{NH}_{4} \mathrm{OH}\right)$ pekat untuk membentuk gel basah. Droplet terlebih dahulu melewati gas amoniak $\left(\mathrm{NH}_{3}\right)$, sebelum mencapai permukaan larutan amonia, dimana terjadi reaksi antara gas $\mathrm{NH}_{3}$ dengan permukaan droplet yang menyebabkan permukaan droplet mengalami pengerasan. Droplet yang telah mengalami pengerasan permukaan dan setelah didiamkan beberapa saat di dalam 
cairan gelasi diambil dari kolom gelasi pada alat gel-casting ini disebut gel basah.

Baker [4], menyatakan bahwa ukuran droplet dikontrol oleh diameter nozzle, kecepatan aliran dan frekuensi vibrasi. Wenli [15] juga menyebutkan bahwa diameter kernel $\mathrm{UO}_{2}$ dapat dikontrol melalui pengaturan frekuensi vibrasi dan kecepatan aliran. Guogao [16], dalam makalahnya menjelaskan bahwa $\mathrm{pH}$ broth, konsentrasi metal, kecepatan aliran broth dan frekuensi vibrasi perlu dioptimisasi untuk mendapatkan diameter kernel yang akurat. IAEA-TECDOC-CD-1674 [17], menggunakan persamaan sederhana untuk memprediksi diameter droplet seperti persamaan (1).

$$
d=\sqrt[3]{\frac{6 \cdot Q}{\pi \cdot f}}
$$

dengan

$$
\begin{array}{ll}
\mathrm{d} & =\text { diameter droplet } \\
\mathrm{Q} & =\text { kecepatan aliran broth } \\
\mathrm{f} & =\text { frekuensi vibrasi }
\end{array}
$$

Berdasarkan paper yang ditulis Hao [18] terdapat persamaan untuk menghitung diameter produk akhir dari proses casting yang menggunakan vibrasi sinusoidal pada frekuensi dan amplitudo tertentu. Persamaan dari Hao dilakukan beberapa modifikasi untuk menghitung diameter droplet sehingga diperoleh persamaan (2).

$$
d=2 \cdot \sqrt[3]{\frac{C \cdot Q}{K \cdot \rho \cdot f}}
$$

$$
\begin{aligned}
& \text { dengan } \\
& \begin{aligned}
\mathrm{d}= & \text { diameter droplet } \\
\mathrm{C}= & \text { konsentrasi metal dalam broth } \\
\mathrm{Q}= & \text { kecepatan aliran broth } \\
\mathrm{K}= & \text { konstanta karakteristik dari nozzle } \\
& \text { alat gel-casting } \\
\rho \quad= & \text { densitas broth } \\
\mathrm{f}= & \text { frekuensi vibrasi }
\end{aligned}
\end{aligned}
$$

\section{METODOLOGI}

\section{Pembuatan broth untuk proses casting}

Bahan untuk pembuatan broth terdiri dari zirconium (IV) nitrate, yttrium (III) nitrate hexahydrate, urea, tetrahydrofurfuryl alcohol (THFA), dan poly vinyl alcohol (PVA). Konsentrasi metal dalam broth ditentukan dengan menimbang sejumlah bahan zirconium (IV) nitrate dan yttrium (III) nitrate hexahydrate. Densitas broth diukur dengan menggunakan alat densitometer.

\section{Proses casting}

Alat gel-casting yang dimiliki PTBBN-BATAN ditunjukkan seperti pada Gambar 1, broth diumpankan melalui tangki umpan untuk selanjutnya dialirkan ke vibrator. Vibrator ini diatur pada frekuensi $100 \mathrm{~Hz}$. Broth diteteskan melalui satu buahnozzle dengan diameter sebesar $1 \mathrm{~mm}$ ke dalam kolom casting yang dialiri gas amoniak $\left(\mathrm{NH}_{3}\right)$ sebelum masuk ke larutan ammonium hidroksida $\left(\mathrm{NH}_{4} \mathrm{OH}\right)$. Gel basah yang dihasilkan oleh alat gel-casting diukur diameternya dengan menggunakan alat mikroskop digital.

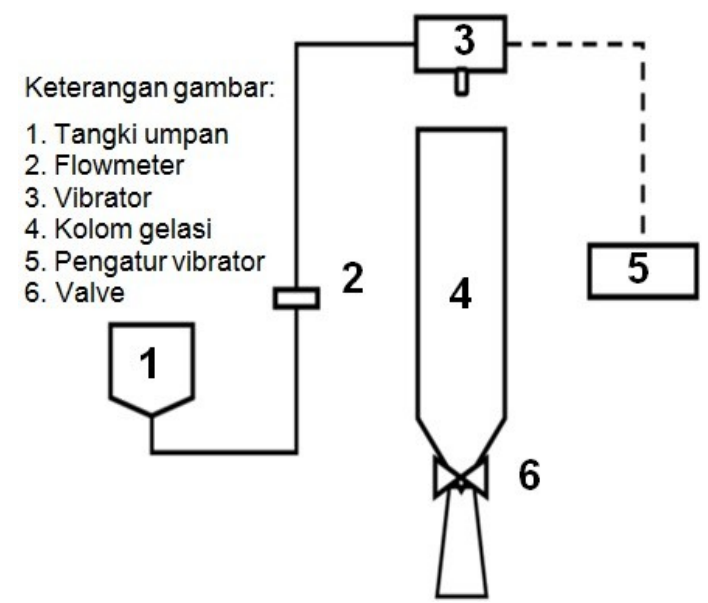

Gambar 1. Diagram alat Gel-Casting

\section{Verifikasi hasil simulasi dengan data eksperimen di laboratorium}

Pada kegiatan ini, dua persamaan matematis diambil dari referensi untuk keperluan perhitungan simulasi diameter gel 
basah, kemudian hasil eksperimen di laboratorium digunakan sebagai verifikasi hasil perhitungan simulasi. Perhitungan simulasi dilakukan dengan menggunakan program komputer matlab. Pada penelitian ini dilakukan simulasi untuk mendekati nilai diameter gel basah yang dihasilkan dari hasil eksperimen di laboratorium. Ada dua simulasi yang dilakukan untuk mendekati hasil eksperimen di laboratorium yaitu simulasi berdasarkan persamaan sederhana yang terdapat pada technical document dari IAEA dan simulasi yang lebih kompleks berdasarkan modifikasi persamaan dari paper yang ditulis oleh Hao dengan memperhitungkan konstanta karakteristik dari nozzle alat casting, frekuensi vibrasi, kecepatan aliran broth, konsentrasi metal dalam broth dan densitas broth.

\section{HASIL DAN PEMBAHASAN}

Hasil penelitian ini telah diperoleh tujuh variasi broth untuk kernel yttriastabilized zirconia dengan spesifikasi seperti ditampilkan pada Tabel 1. Pada proses gel-casting, frekuensi vibrator yang digunakan adalah $100 \mathrm{~Hz}$. Tabel 1 juga memperlihatkan kecepatan aliran broth yang melewati nozzle dan diameter rerata gel basah yang diperoleh dari eksperimen untuk setiap sampel, sedangkan mikrograf gel basah sebagai hasil analisis dari mikroskop digital untuk masing-masing sampel ditunjukkan pada Gambar 2 hingga 8.

Pada Gambar 9, ditampilkan hasil simulasi dan data eksperimen dengan variasi frekuensi vibrasi. Variasi diameter gel basah pada setiap sampel hasil eksperimen di laboratorium dimungkinkan karena adanya noise pada alat vibrator sehingga mempengaruhi frekuensi vibrasi, friksi pada pipa alat casting sehingga mempengaruhi kecepatan aliran broth. Selain itu berkurangnya volume broth pada tangki pengumpan alat gel-casting pada saat pembentukan droplet sebagai fungsi waktu juga dapat mempengaruhi kecepatan aliran broth sehingga menyebabkan variasi diameter gel basah. Hasil simulasi menggunakan persamaan IAEA-TECDOCCD-1674 menunjukkan bahwa frekuensi vibrasi pada alat gel-casting yang semakin besar memberikan diameter gel basah yang semakin kecil. Hal ini sesuai dengan persamaan (1) bahwa diameter gel basah berbanding terbalik dengan frekuensi vibrasi, sehingga semakin besar frekuensi pada alat vibrasi maka gel basah yang dihasilkan akan semakin kecil. Simulasi untuk sampel no 3, 4, 5 dan 6 berhimpit karena pada kecepatan aliran broth yang sama yaitu $5 \times 10^{-7} \mathrm{~m}^{3} \mathrm{~s}^{-1}$. Perbandingan diameter gel basah hasil simulasi dengan data ekperimen di laboratorium didapatkan penyimpangan sebesar 0,2239 (sampel 1), 0,0504 (sampel 2), 0,1710 (sampel 3), 0,1314 (sampel 4), 0,2306 (sampel 5), 0,1471 (sampel 6) dan 0,0894 (sampel 7). Dari hasil analisis ini diperoleh rerata penyimpangan antara data eksperimen dengan simulasi sebesar 0,1491.

Tabel 1. Data proses gel-casting broth dan diameter gel basah untuk frekuensi vibrator $100 \mathrm{~Hz}$.

\begin{tabular}{ccccc}
\hline Sampel & $\begin{array}{c}\text { Konsentrasi metal } \\
\text { dalam broth }\left(\mathrm{kg} \mathrm{m}^{-3}\right)\end{array}$ & $\begin{array}{c}\text { Densitas broth } \\
\left(\mathrm{kg} \mathrm{m}^{-3}\right)\end{array}$ & $\begin{array}{c}\text { Kecepatan aliran } \\
\text { broth }\left(\mathrm{m}^{3} \mathrm{~s}^{-1}\right)\end{array}$ & $\begin{array}{c}\text { Diameter rerata } \\
\text { gel basah }(\mathrm{m})\end{array}$ \\
\hline Sampel 1 & 184,4649 & $1.108,0$ & $2,667 \times 10^{-7}$ & 1,4039 \\
Sampel 2 & 245,2184 & $1.662,0$ & $4,200 \times 10^{-7}$ & 1,9305 \\
Sampel 3 & 196,9787 & $1.120,5$ & $5,000 \times 10^{-7}$ & 1,8797 \\
Sampel 4 & 255,6532 & $1.480,0$ & $5,000 \times 10^{-7}$ & 1,9358 \\
Sampel 5 & 266,3385 & $1.148,3$ & $5,000 \times 10^{-7}$ & 1,7954 \\
Sampel 6 & 266,3385 & $1.142,3$ & $5,000 \times 10^{-7}$ & 1,9136 \\
Sampel 7 & 254,1211 & $1.154,6$ & $4,500 \times 10^{-7}$ & 1,9219 \\
\hline
\end{tabular}




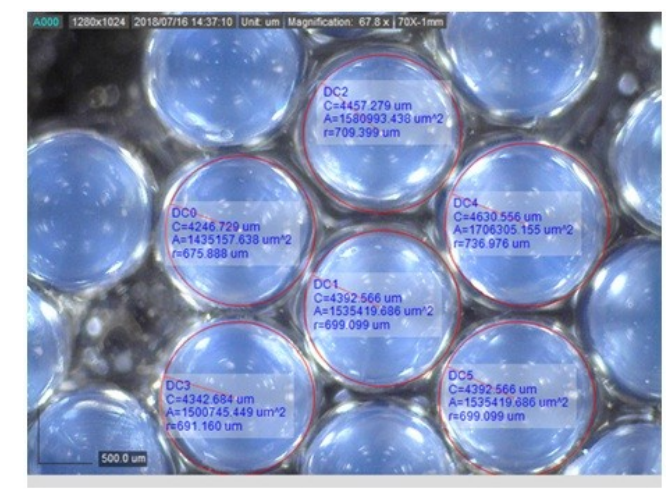

Gambar 2. Gel basah sampel 1

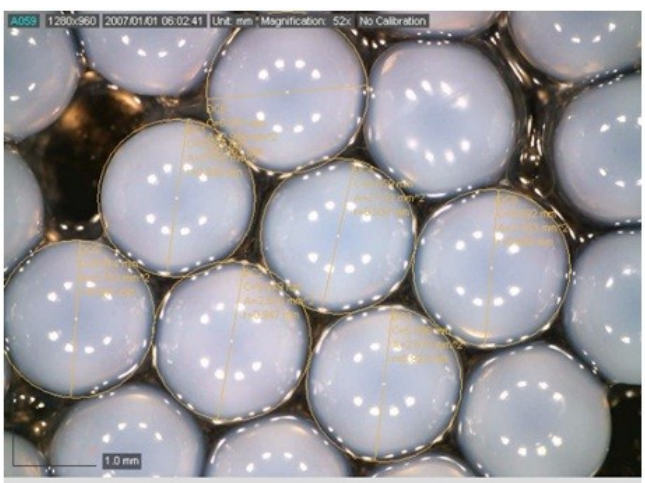

Gambar 4. Gel basah sampel 3

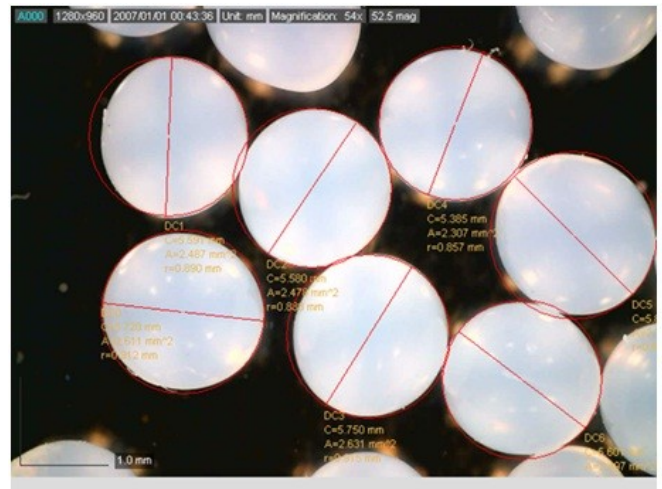

Gambar 6. Gel basah sampel 5

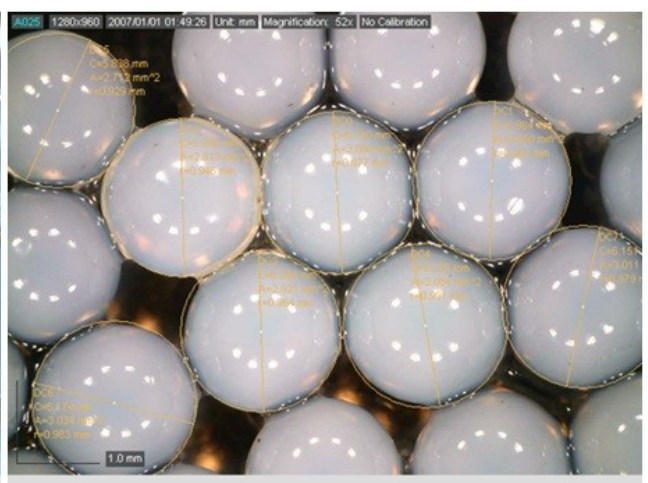

Gambar 3. Gel basah sampel 2

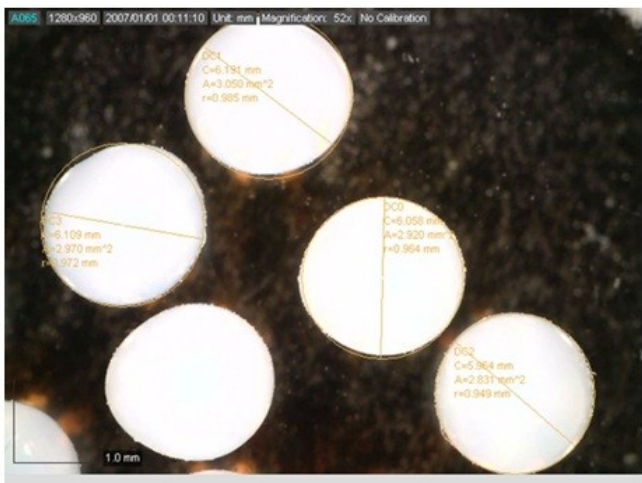

Gambar 5. Gel basah sampel 4

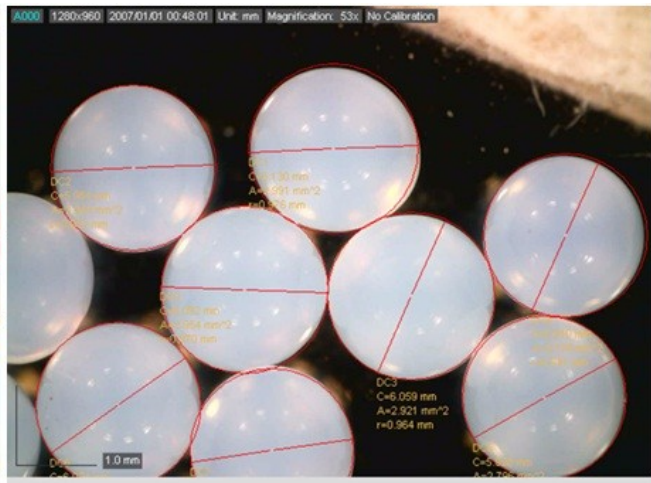

Gambar 7. Gel basah sampel 6

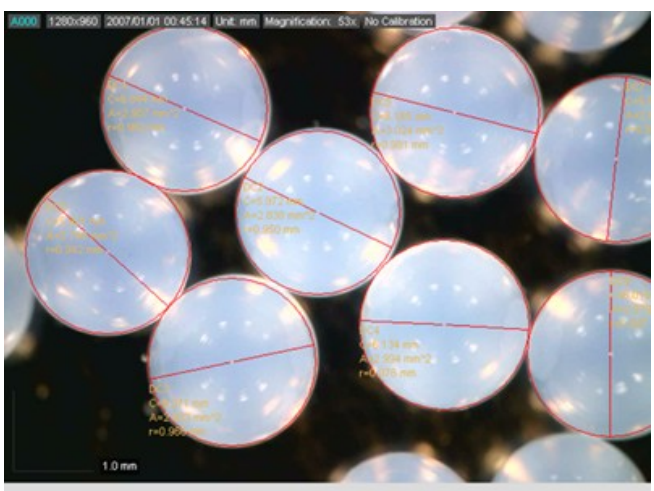

Gambar 8. Gel basah sampel 7 


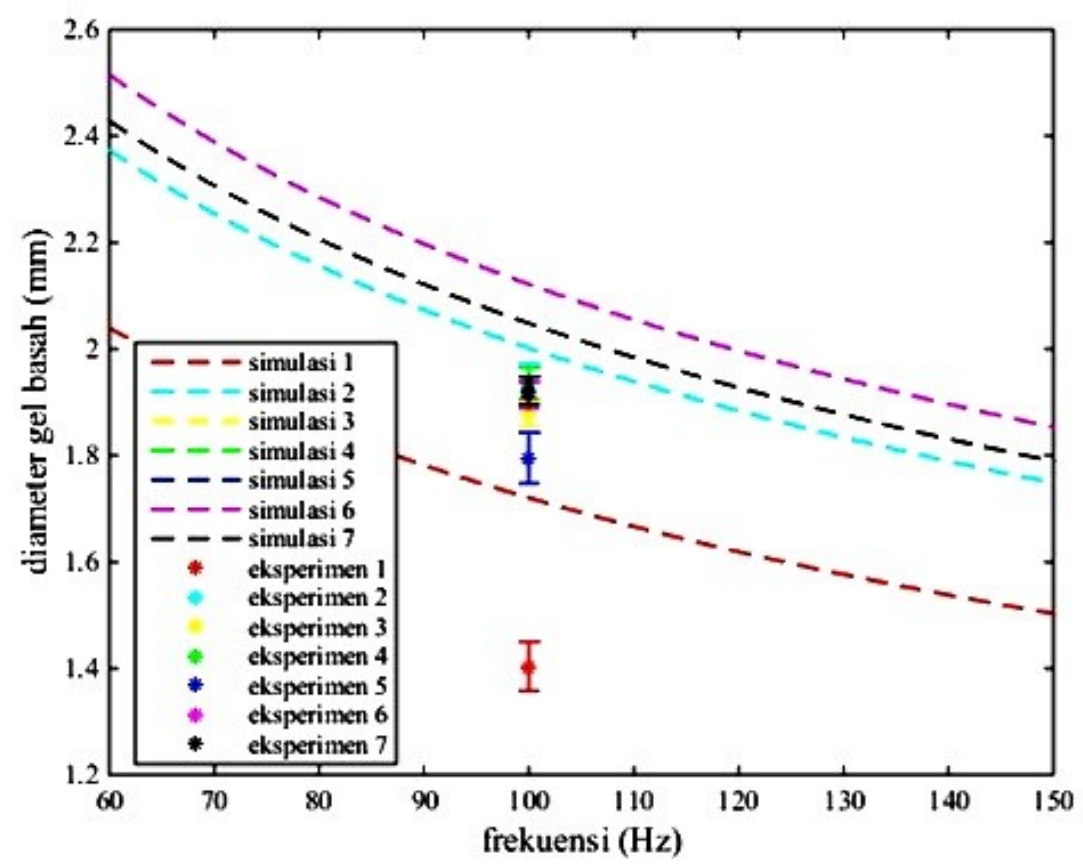

Gambar 9. Hubungan antara diameter gel basah dengan frekuensi vibrasi pada eksperimen dan hasil simulasi menggunakan persamaan dari IAEA-TECDOC-CD-1674 [17]

Gambar 10 menunjukkan bahwa setelah dilakukan beberapa eksperimen pada frekuensi vibrasi tetap $100 \mathrm{~Hz}$ dengan kecepatan aliran broth yang berbeda terlihat bahwa diameter gel basah yang diperoleh dari eksperimen memiliki kecenderungan yang sama dengan hasil simulasi dimana semakin besar kecepatan aliran broth maka akan diperoleh gel basah dengan diameter yang semakin besar. Hal ini dibuktikan bahwa pada eksperimen di laboratorium untuk sampel 1 dengan kecepatan aliran broth paling kecil maka diperoleh diameter gel basah paling kecil. Meskipun diameter gel basah sampel 1 dari hasil eksperimen di laboratorium diperoleh $1,4039 \mathrm{~mm}$ sedangkan dari simulasi sebesar $1,7206 \mathrm{~mm}$ sehingga ada penyimpangan sebesar 0,2239. Persamaan dari Hao selanjutnya digunakan yang sudah dimodifikasi untuk mendekati diameter gel basah yang diperoleh dari eksperimen di laboratorium.

Pada Gambar 11 terlihat bahwa hasil perhitungan simulasi untuk sampel 5 dan sampel 6 berhimpitan. Fenomena ini sudah diprediksi karena kecepatan aliran broth untuk kedua sampel tersebut sama besarnya. Selain itu, karakteristik broth sampel 5 dan sample 6 seperti yang sudah dijelaskan pada Tabel 1 yaitu konsentrasi metal dalam broth dan densitas broth memiliki nilai yang hampir sama besarnya. Sebagai contoh dari perhitungan simulasi diperoleh diameter gel basah untuk sampel 5 sebesar $2,0234 \mathrm{~mm}$ dan sampel 6 sebesar $2,0269 \mathrm{~mm}$ pada frekuensi vibrasi $100 \mathrm{~Hz}$. Berdasarkan perhitungan diperoleh diameter gel basah hasil simulasi berdasarkan modifikasi persamaan yang tertulis pada makalah Hao dapat mendekati diameter gel basah hasil eksperimen di laboratorium. Hal ini dimungkinkan karena Hao menggunakan nilai $\mathrm{K}$ yaitu konstanta karakteristik dari nozzle alat gel-casting. Sehingga pada konstanta $\mathrm{K}=1,12$ memberikan rerata penyimpangan terkecil sebesar 0,0843. Untuk penyimpangan tiap-tiap sampel dibandingkan dengan hasil simulasi sebagai berikut: 0,0462 (sampel 1), 0,2041 (sampel 2), 0,0247 (sampel 3), 0,0720 (sampel 4), 0,1612 (sampel 5), 0,0801 (sampel 6) dan 0,0016 (sampel 7). 


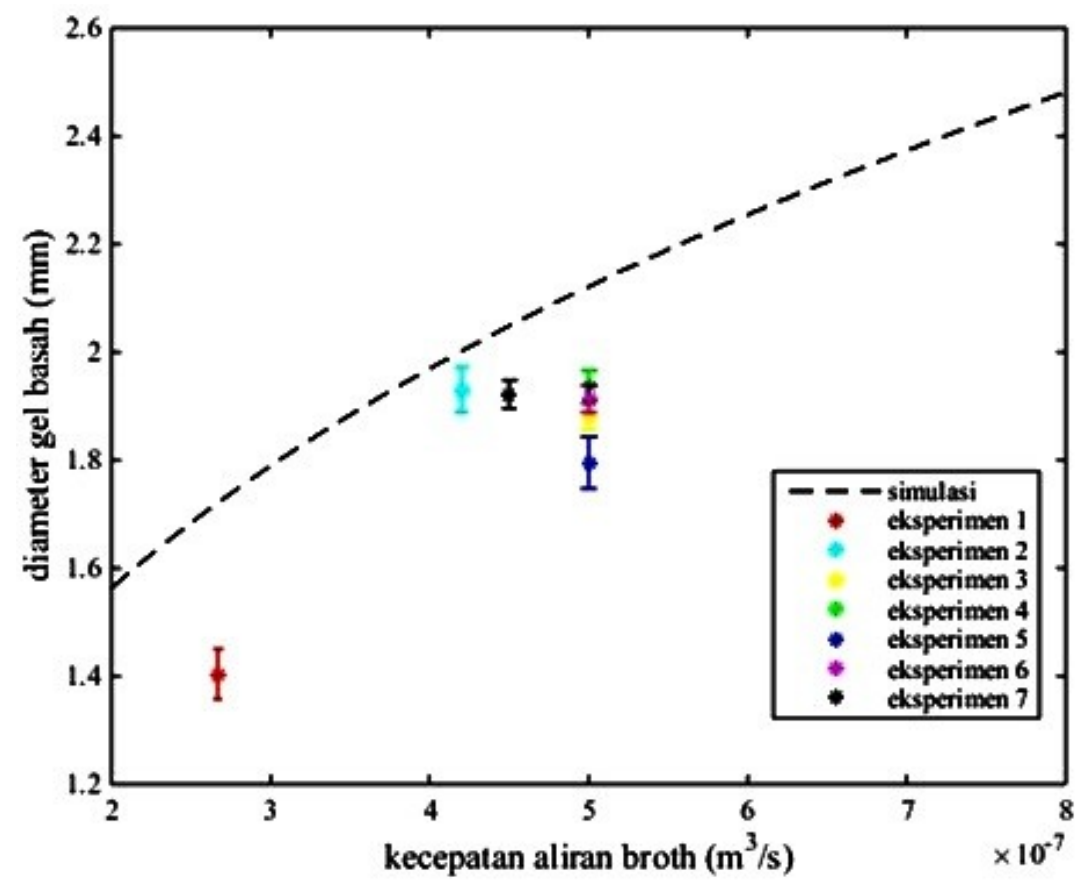

Gambar 10. Hubungan antara diameter gel basah dengan kecepatan aliran broth pada eksperimen dan simulasi menggunakan persamaan dari IAEA-TECDOC-CD-1674 [17]

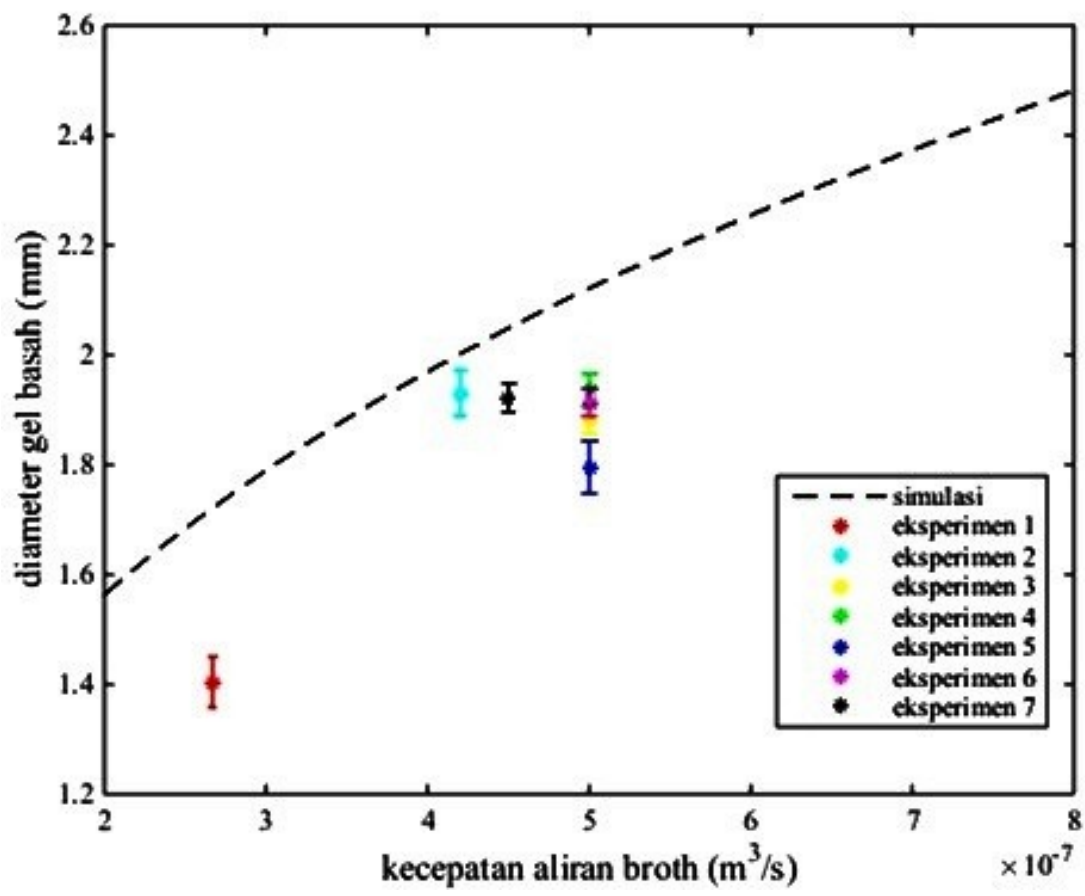

Gambar 11. Hubungan antara diameter gel basah dengan frekuensi vibrasi, data eksperimen dengan hasil simulasi berdasarkan modifikasi persamaan dari Hao

Gambar 12 menunjukkan bahwa pada simulasi sampel 5 dan sampel 6 berhimpit sama seperti Gambar 11. Sebagai contoh dari perhitungan simulasi untuk kecepatan aliran broth $5 \times 10^{-7} \mathrm{~m}^{3} \mathrm{~s}^{-1}$ diperoleh diameter gel basah sampel 5 sebesar 2,0234 mm dan sampel 6 sebesar 2,0269 $\mathrm{mm}$ sehingga jika ditampilkan secara 
visual terlihat berhimpit. Hasil perhitungan simulasi memiliki kesesuaian dengan data eksperimen di laboratorium yaitu semakin besar kecepatan aliran broth maka gel basah yang dihasilkan alat gel-casting juga semakin besar.

Hubungan antara diameter gel basah dengan konsentrasi metal dalam broth divisualisasikan pada Gambar 13 dengan menggunakan modifikasi persamaan dari Hao untuk mendekati hasil eksperimen di laboratorium. Pada Gambar 13 terlihat bahwa baik dari perhitungan simulasi maupun dari data eksperimen di laboratorium memiliki kecenderungan yang sama yaitu semakin besar konsentrasi metal dalam broth maka diameter gel basah yang dihasilkan alat casting juga akan semakin besar. Dari hasil perhitungan simulasi untuk konsentrasi metal dalam broth $200 \mathrm{~kg} / \mathrm{m} 3$ diperoleh diameter gel basah untuk sampel $1=1,5094 \mathrm{~mm}$, sampel $2=1,5341 \mathrm{~mm}$, sampel $3=1,8542 \mathrm{~mm}$, sampel 4=1,6899 $\mathrm{mm}$, sampel $5=1,8391 \mathrm{~mm}$, sampel $6=1,8423 \mathrm{~mm}$ dan sampel $7=1,7724 \mathrm{~mm}$, sehingga jika divisualisasikan dalam bentuk grafik maka sampel 5 dan sampel 6 akan terlihat berhimpit.

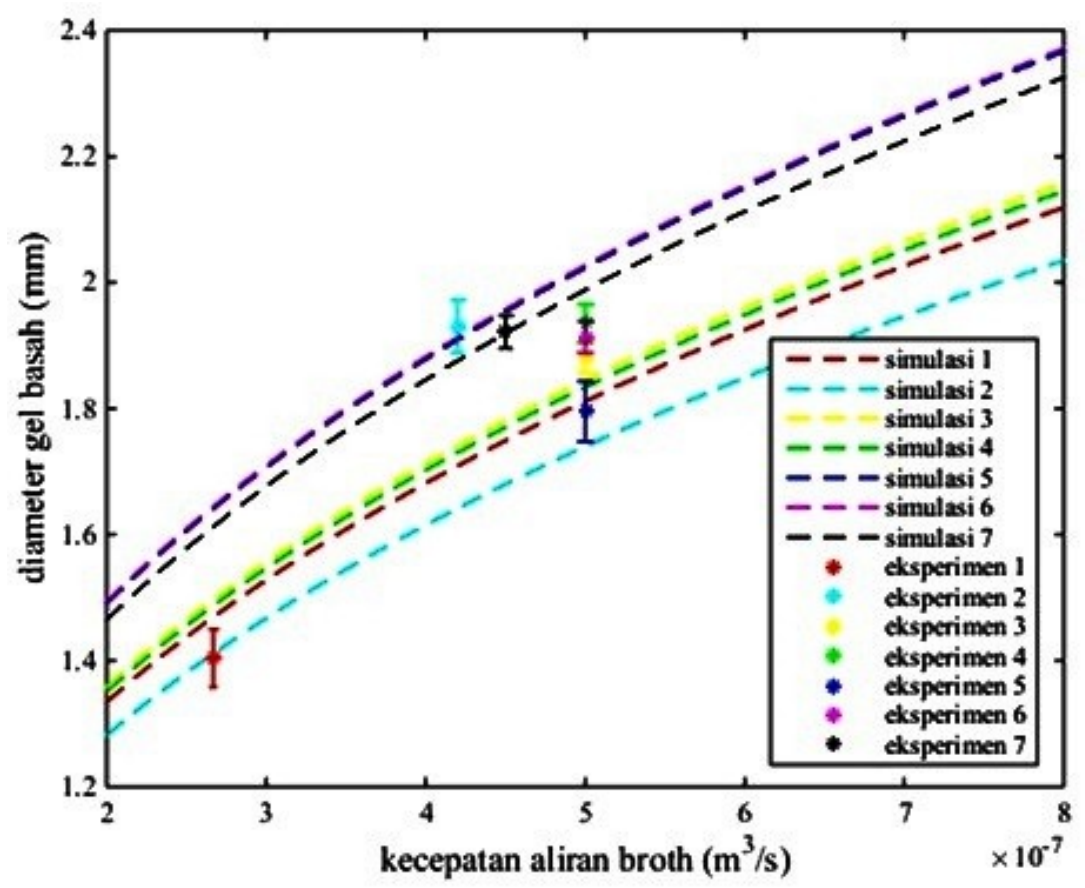

Gambar 12. Hubungan antara diameter gel basah dengan kecepatan aliran broth, data eksperimen dengan hasil simulasi berdasarkan modifikasi persamaan dari Hao

Untuk memberikan pengetahuan seberapa besar pengaruh densitas broth pada ukuran diameter gel basah yang dihasilkan alat gel-casting, dilakukan simulasi berdasarkan persamaan yang sudah dimodifikasi dari Hao pada Gambar 14. Dari perhitungan simulasi dengan menggunakan densitas broth semakin besar maka diameter gel basah yang diperoleh dari alat gel-casting akan semakin kecil. Sebagai contoh jika menggunakan densitas broth sebesar $1200 \mathrm{~kg} \mathrm{~m}^{-3}$ dari hasil perhitungan simulasi diperoleh diameter gel basah untuk sampel $1=1,4307 \mathrm{~mm}$, sampel $2=1,8302 \mathrm{~mm}$, sampel $3=1,8031 \mathrm{~mm}$, sampel 4=1,9668 $\mathrm{mm}$, sampel $5=1,9939 \mathrm{~mm}$, sampel $6=1,9939 \mathrm{~mm}$ dan sampel 7=1,8952 $\mathrm{mm}$. Sehingga jika simulasi untuk sampel 5 dan sampel 6 divisualisasikan dalam bentuk grafik maka sampel 5 dan sampel 6 terlihat berhimpit. 


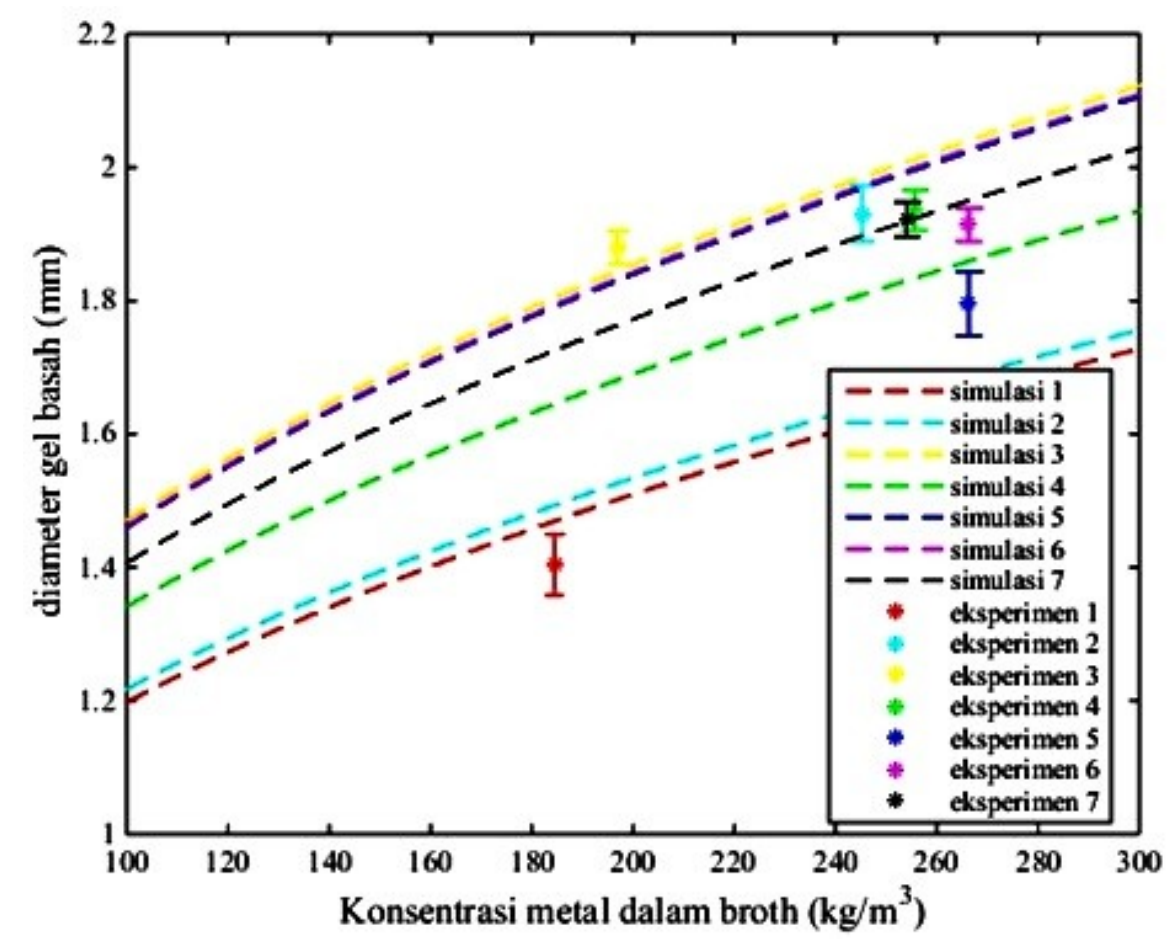

Gambar 13. Hubungan antara diameter gel basah dengan konsentrasi metal dalam broth, data eksperimen dengan hasil simulasi berdasarkan modifikasi persamaan dari Hao

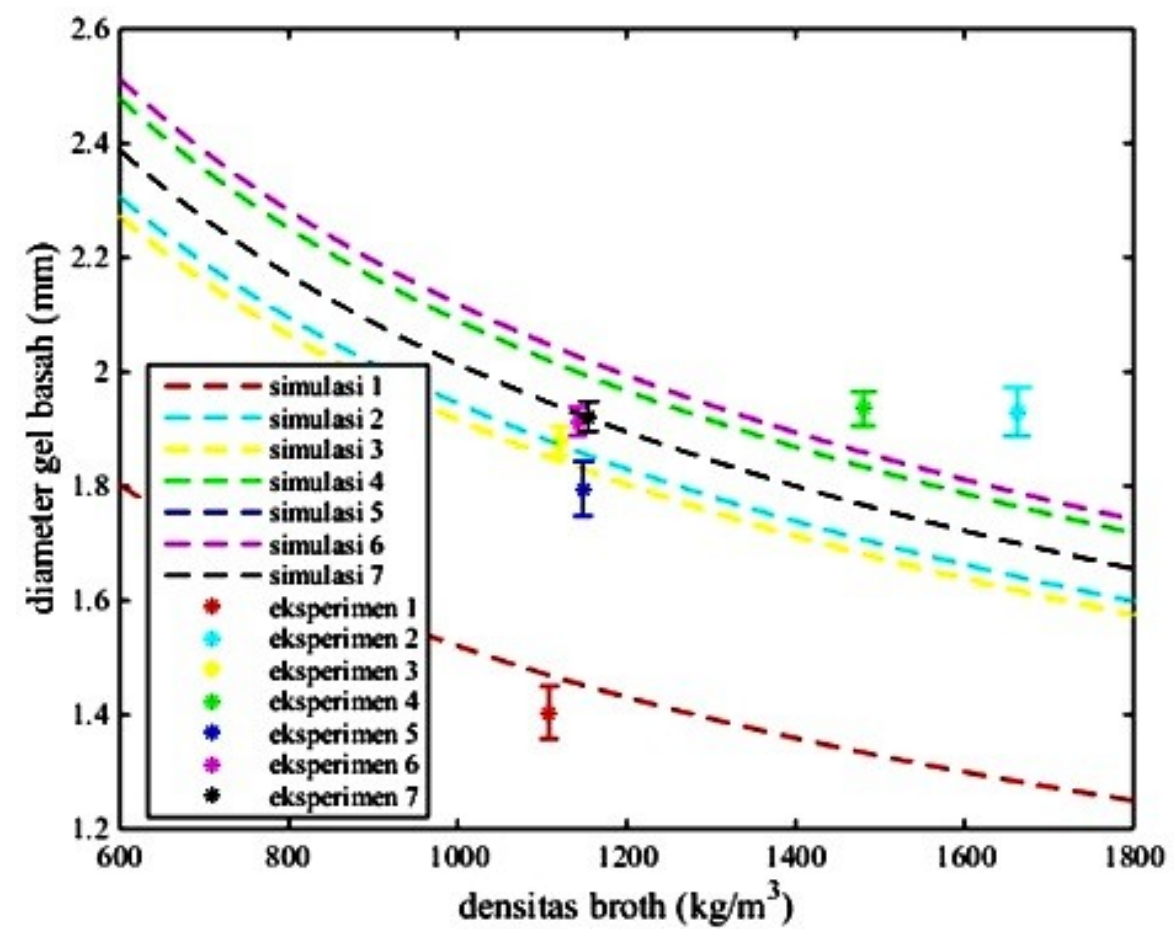

Gambar 14. Hubungan antara diameter gel basah dengan densitas broth, data eksperimen dengan hasil simulasi berdasarkan modifikasi persamaan dari Hao 


\section{SIMPULAN}

Diameter gel basah hasil eksperimen di laboratorium menggunakan alat gel-casting yang dimiliki PTBBN-BATAN dapat didekati dengan menggunakan modifikasi persamaan yang diberikan oleh Hao dalam penelitiannya dengan menggunakan konstanta karakteristik dari nozzle alat gel-casting sebesar 1,12 sehingga memberikan rerata penyimpangan terkecil sebesar 0,0843. Bila hasil eksperimen di laboratorium didekati dengan persamaan yang diberikan di TECDOC-CD1674 IAEA diperoleh rerata penyimpangan antara data eksperimen dengan simulasi sebesar 0,1491. Dari kedua persamaan yang digunakan dalam perhitungan simulasi dapat disimpulkan bahwa modifikasi persamaan dari Hao lebih mendekati hasil eksperimen di laboratorium dari pada persamaan dari IAEA. Hal ini menunjukkan bahwa diameter gel basah yang dihasilkan alat gel-casting dipengaruhi tidak hanya kecepatan aliran broth dan frekuensi vibrasi akan tetapi juga dipengaruhi densitas broth dan konsentrasi metal dalam broth.

\section{UCAPAN TERIMA KASIH}

Ucapan terimakasih disampaikan kepada rekan-rekan yang telah membantu melakukan penelitian di laboratorium sehingga dapat menyusun karya tulis ilmiah ini. Penelitian ini didanai oleh Kemenristek Dikti, Flagship Insinas BATAN tahun 2018.

\section{DAFTAR PUSTAKA}

[1]. W. K. Kim, Y. W. Lee, M. S. Cho, "Nondestructive measurement of the weight of kernels in a simulated cylindrical fuel compact for HTGR using X-ray computed tomography," Nuclear Engineering and Design, vol. 241, no.9, pp. 3748-3752, 2011.

[2]. Z. Xiangwen, et al., "Preparation of ammonium diuranate particles by external gelation process of uranium in INET," Nuclear Engineering and Design, vol. 250 (Supplement C), pp. 192-196, 2012.

[3]. G. Brähler, et al., Improvements in the fabrication of HTR fuel elements, "Nuclear Engineering and Design," vol. 251 (Supplement C), pp. 239-243, 2012

[4]. M. P. Baker, et.al, "Selection and properties of alternative forming fluids for TRISO fuel kernel production," Journal of Nuclear Materials, vol. 432, no. 1, pp. 395-406, 2013.

[5]. J. A. Phillips, S. G. Nagley, and E. L. Shaber, "Fabrication of uranium oxycarbide kernels and compacts for HTR fuel," Nuclear Engineering and Design, vol. 51(Supplement C), pp. 261281, 2012.

[6]. M. Brykala, and M. Rogowski, "Preparation of microspheres of carbon black dispersion in uranyl-ascorbate gels as precursors for uranium carbide," Progress in Nuclear Energy, vol. 89(Supplement C), pp. 132-139, 2016.

[7]. N. N. Ngoepe, and J. P. R. de Villiers, "The thermal expansion of $3 \mathrm{C}-\mathrm{SiC}$ in TRISO particles by high temperature Xray diffraction," Journal of Nuclear Materials, vol. 438, no. 1, pp. 88-93, 2013.

[8]. T. J. Gerczak, et al., "SiC layer microstructure in AGR-1 and AGR-2 TRISO fuel particles and the influence of its variation on the effective diffusion of key fission products," Journal of Nuclear Materials, vol. 480(Supplement C), pp. 257-270, 2016.

[9]. E. López-Honorato, P.J. Meadows, and P. Xiao, "Fluidized bed chemical vapor deposition of pyrolytic carbon - I:Effect of deposition conditions on microstructure," Carbon, vol. 47, no.2, pp. 396-410, 2009.

[10]. G. Wenli, et al., "Diameter deviation calculation for $\mathrm{UO}_{2}$ kernel by sol-gel process. Nuclear Engineering and Design, vol. 241, no. 8, pp. 2964-2967, 2011. 
[11]. K. Bari, et al., "Characterization of the porosity in TRISO coated fuel particles and its effect on the relative thermal diffusivity," Nuclear Engineering and Design, vol. 265 (Supplement C): pp. 668-674, 2013.

[12]. M. P. Baker, et al., "Straight-chain halocarbon forming fluids for TRISO fuel kernel production-tests with yttria-stabilized zirconia microspheres," Journal of Nuclear Materials, vol. 458 (Supplement C), pp. 77-86, 2015.

[13]. R. D. Hunt, et al., "Key process parameters to modify the porosity of cerium dioxide microspheres formed in the internal gelation process," Journal of Nuclear Materials, vol. 495, pp. 33-37, 2017

[14]. R.D. Hunt, et al., "The addition of silicon carbide to surrogate nuclear fuel kernels made by the internal gelation process," Journal of Nuclear Materials, vol. 401, no.1, pp. 55-59, 2010.

[15]. G. Wenli, et al., "Preparing $\mathrm{UO}_{2}$ kernels by gel-casting. Nuclear Science and Techniques, vol. 20, pp. 124-128, 2009.

[16]. W. J. Guogao, M. Yong, G. Xingyu, S. Zhao, C. H. Deng, "Precisely Controlling Preparation of Ceria-Stabilized Zirconia Microspheres of $\sim 100$ micron by external gelation," International Journal of Applied Ceramic Technology, pp. 1-7, 2016.

[17]. IAEA, IAEA-TECDOC-CD-1674, 2012.

[18]. S. Hao, et al., "Large-scale production of $\mathrm{UO}_{2}$ kernels by sol-gel process at INET," Nuclear Engineering and Design, vol. 271, pp. 158-161, 2014 